\title{
Money Laundering Criminal Justice System
}

\author{
Tjotjoe Sandjaja Hermanto $^{1}$, Faisal Santiago ${ }^{2}$ \\ Student at Doctoral of Law, Universitas Borobudur, Jakarta Indonesia ${ }^{1}$, Universitas \\ Borobudur, Faculty of Law, Jakarta, Indonesia ${ }^{2}$ \\ \{mr.tjoetjoe@yahoo.com ${ }^{1}$, faisalsantiago@borobudur.ac.id $\left.{ }^{2}\right\}$
}

\begin{abstract}
One of the acts of corruption is money laundering, and this is, of course, very contrary to Justice in society. This study uses a normative juridical approach. This research aims to convict the perpetrators of money laundering with reverse proof and then carry out the punishment following the Criminal Procedure Code. This study's conclusion is Concerning The Crime of Money Laundering, that the system of "inverse proof of a limited and balanced.
\end{abstract}

Keywords: corruption; criminal Justice; money laundering

\section{Introduction}

Money laundering as an internationally charged crime is not new in many countries, including Indonesia. Such crimes certainly have a tremendous negative impact on a country's economy. Countries worldwide and international organizations feel encouraged and motivated to pay more serious attention to preventing and eradicating money-laundering crimes. There are none other than because the crime of money laundering (money laundering) directly or indirectly can affect the economic system, and the influence negatively impacts the economy itself. In practice, many potential funds are not utilized optimally because money launderers often make sterile investments, such as investments in property in countries considered safe, even with so many results.

The development of technology is advancing rapidly, bringing the master to the growth in various sectors, both in politics, economics, and socio-culture. One of the growing problems is criminality. However, the legal tools to prevent and eradicate corruption themselves are not adequate and still far away, so that various types of crimes either committed by individuals, groups, or corporations quickly occur and produce a large amount of wealth. These crimes are saved within the boundaries of a country and extend across other countries' borders, often referred to as transnational crime. In international crimes, the proceeds of crime are usually committed by perpetrators hidden, then expelled again as if from legal results.

Indonesia has many favorable factors to do money laundering, so there is no doubt the state of Indonesia is labeled as a country that does not cooperatively fight the type of crime of money laundering. These are proved by several systems embraced by the Indonesian state, such as a free foreign exchange system, a bank confidentiality system. On the other hand, Indonesia still needs liquidity or the absence of strict juridical tools for anti-money theft. Therefore, in 2001 precisely on June 22, the Financial Action Task Force (FATF) included Indonesia and 19 other countries on the blacklist of Non-Cooperative Countries or Territories (NCCTs) or non-cooperative areas in handling money laundering cases. The nineteen other countries are Egypt, Russia, Hungary, Israel, Lebanon, Philippines, Myanmar, Nauru, Nigeria, 
Niue, Cook Island, Dominican Republic, Guatemala, St. Kitts and Nevis, St. Vincent, and the Grenadines, and Ukraine.

Crimes such as money laundering or better known as money laundering, are a very familiar term often heard from various media. Therefore many understandings are developing now concerning the term money poisoning. In today's period, money Laundering is commonly used to describe efforts made by a person or legal entity to legalize the dirty money obtained from the proceeds of criminal acts. According to the Black Law Dictionary, as cited by Bambang Septioprojo, money laundering is interpreted as a term used to describe the investment or transfer of money resulting from crimes such as corruption, drug dealing, and other illegal sources, which are strongly related to the crime of laundering money and the proceeds of crime are put into legal or legitimate channels so that the origin can not be traced."

The definition of money laundering in Law No. 15 of 2002, as amended into Law No. 25 of 2003 on The Crime of Money Laundering, which as amended again in law Law No. 8 of 2010 on prevention eradication of money laundering crimes. that in Article 1 number 1 as follows: "Money laundering is the act of placing, transferring, paying, spending, giving, donating, depositing, taking abroad, exchanging, or other acts of property known or suspected to be the result of a criminal act to hide, or disguise the origin of the property so that it appears to be a legitimate property."

Such crime mode certainly passes through the stages. The first stage is to place (deposit) the money resulting from the crime into the financial system or in a particular Bank. The second stage is lawyering. In this stage, the purgatory of cash is trying to disconnect the source's proceeds of corruption. The Third Stage is Integration; at this stage, the money laundered back into circulation in net income is even an object of tax (taxable). The Indonesian government's efforts and efforts, one of which is to suppress the rise of criminal acts of money laundering or money laundering, are to pay special attention to proof's aspect. The evidence referred to on the side is related to whether or not the accused committed the alleged act. It is the essential part that must consider criminal procedural law and human rights.

The system described is essential because the implementation of Law Number 8 of 2010 concerning the Crime of Money Laundering adopts two Proof systems: a limited reversal proof system and a balanced and negative system of proof as stipulated in the regulations. The implementation of the reverse proof system adopted by the TPPU Law is not easy. Optimally. Several juridical problems may occur, such as the contradiction of this reverse proof system with the principle of criminal law, namely the presumption of innocence. Looking at the description above, then in this paper, the author wants to analyze and give the title as follows: Limited Reverse Evidentiary System In the Perspective of The Principle of Presumption of Innocence.

\section{Research Methods}

The method used in the form of normative juridical research using the statute approach is used to research, review, study, and understand the laws and regulations governing the Limited Reverse Proof System in the Perspective of the Principle Presumption of Innocence.

\section{Result and Discussion}


Based on the background as outlined above, there are several problem formulations as follows:

a. How is the reverse proof system limited according to Law Number 8 years 2010 ?

b. How is the Inverse Evidentiary System Limited In The Basic Perspective of Presumption of Innocence?

\subsection{Understanding the Limited Reverse Proof System and Money Laundering}

\section{a) Understanding Money Laundering}

Before discussing related to the understanding of the "Limited reverse proof system," it becomes necessary to explain in advance the knowledge of "money laundering." There is nothing uniform about money laundering because countries have their definitions according to the laws applicable in their countries.

There are several understandings related to the crime of money laundering (money laundering). In general, these definitions do not differ from each other. Black's Law Dictionary gives the sense of money laundering as the term used it describe investment or other transfer of money flowing from racketeering, drug transaction, and other illegal sources into legitimate channels so that it is unable to trace the source. Money laundering is the process of removing traces of the origin of money resulting from illegal activities or crimes through a series of investment or transfer activities carried out many times intending to obtain legal status for money invested or destroyed into the financial system.

Some definitions of money laundering, according to experts, are as follows:

1. According to Welling, Money laundering is the process of concealing the existence of unauthorized sources or applications of unauthorized opinions so that the revenue becomes legitimate.

2. According to Fraser, Money laundering is a straightforward process where dirty money is processed or laundered through legitimate or clean sources so that people can enjoy the benefits of not being halal safely.

3. According to Prof. Dr.M. Giovanoli, Money laundering is a process. In such a way, the wealth obtained from the crime accumulates as if it comes from a legitimate source.

Understanding of perpetrators of money laundering crimes according to Law No. 8 of 2010 concerning the prevention and eradication of money laundering crimes in Porigin paragraph (3) as follows: Everyone who places, transfers, diverts, spends, pays, and entrusts, entrusts, brings abroad, change the form, exchange for foreign currency or securities or other acts of property known or supposed to be the result of criminal acts as referred to in Porigin2 paragraph (1) with the aim of hiding or disguising the origin of property convicted of money laundering crimes with a maximum imprisonment of 20 (twenty) years and a maximum fine of Rp.10,000,000,000.00 (ten billion rupiahs).

\section{b) Definition of Limited Reverse Proofing System}

The definition of a "limited reverse proof system " is contained in Article 77 of Law No. 8 of 2010 adheres to the existence of two evidentiary systems, namely "a limited and balanced reverse evidentiary system" and a "negative system" as stipulated in KUHAP. In the explanation of Law No. 8 of 2010, the definition of "limited and balanced reverse proof," i.e., the defendant has the right to prove that he did not commit the crimes alleged against him, and the public prosecutor is still obliged to prove his indictment. The words with the intention of 
"limited." Suppose the accused can confidently demonstrate that the allegations directed against him are not proven or untrue. In that case, the defendant did not commit the criminal act as alleged by the public prosecutor. Because JPU, still obliged to prove the indictment.

\subsection{Limited Reverse Evidentiary System and the Principle of Presumption of Innocence}

\section{a) Limited Reverse Proofing System}

It is necessary first to discuss related to various types related to proof. In Perspektive knowledge of Criminal Law known there are 3 (three) theories about the burden of proof are as follows:

1. The burden of proof on the Public Prosecutor. The public prosecutor does not exercise the right to deny the right granted by u-law to the accused but does not mean that the public prosecutor does not have the right to judge from the point of view of the public prosecutor in his requisitor. This evidentiary burden theory's logical consequence is that the Public Prosecutor must prepare evidence and evidence accurately. Otherwise, it will be difficult to convince the judge about the defendant's guilt. The logical consequences of the burden of proof are on the Public Prosecutor. There correlates the principle of presumption of innocence and actualization of the direction of not blaming oneself. This theory of evidentiary burden is known in Indonesia that the provisions of Article 66 KUHAP expressly state that "suspects or defendants are not burdened with evidentiary obligations." Such evidentiary loads can be categorized as "ordinary" or "conventional" evidentiary loads.

2. Proof's burden on The Accused, The defendant actively stated that he was not a criminal. Therefore, the defendant is in front of a court hearing that will prepare all the burdens of proof, and if it can not prove, the defendant is found guilty of a criminal offense.

3. They have balanced Evidentiary Load. Concretizing this principle, both the Public Prosecutor and the accused and his Legal Counsel prove each other before the trial. The theory of reversal of the burden of proof is "limited and balanced" in the sense that the accused and the Claimant prove each other's guilt or innocence.

When viewed intensely, in detail, and particularly the provisions of Article 77 of Law No. More 8 of 2010 apply or adhere to two evidentiary systems, namely "a limited and balanced reverse evidentiary system" and a "negative system" regarding how the provisions of KUHAP.

Explanation Law No. 8 of 2010, the definition of "limited and balanced reverse proof," i.e., the defendant has the right to prove that he did not commit the crimes alleged against him and the public prosecutor remains obliged to prove his indictment. The words "limited" are intended. Suppose the accused can confidently demonstrate that the allegations directed against him are not proven or untrue. In that case, this does not mean that the defendant did not commit a criminal offense following what was alleged by the JPU. Because JPU, still obliged to prove the indictment.

Related to this serious crime, action or quick steps have been taken by the government by inviting Law No. 15 of 2002, which was refined into Law No. 25 of 2003 which has now been amended into Law No. 8 of 2010 on the Prevention and Eradication of Money Laundering Crimes. The product law Money Laundering is a form of commitment, understanding, and political will of the Indonesian state to combat money laundering. This concept is a revolutionary policy outlined in this regulation is the use of the burden of proof upside down (Omkering van het Bewijslat). 
Give the defendant the right to explain and help facilitate the indictment proceedings that the Public Prosecutor has previously traced. It is based on Article 78 Law Number 8 the Year 2010 paragraph (1), states that in the examination at the court session as referred to in Article 77 , the judge ordered the defendant to prove the wealth related to the case is not derived or associated with the criminal act as referred to in Article 2 paragraph (1).

Then in paragraph (2) states, "the defendant proves the property related to the case is not derived or associated with the criminal act as referred to in Article 2 paragraph (1) by submitting sufficient evidence.

\section{b) The Principle of Presumption of Innocence in the Reverse Evidentiary System}

The Basic Concept of Presumption of Innocence and its Arrangements in Indonesia. That the principle of presumption of innocence is a manifestation of the function of criminal Justice (modern) that is deliberately used as a principle in carrying out acts of the violent takeover or retaliation of an institution appointed by the state. As such, all infringement of rights committed by a person must be resolved following applicable legal procedures. The sound of this presumption of innocence states. "Any person who is suspected, arrested, detained, prosecuted, and confronted before the court, must plead not guilty before a court ruling, which declares his or her guilt and obtains permanent legal force."

The application of the Principle of Presumption of Innocence is very closely related to human rights that must be respected and upheld. The consequence is that the suspect or defendant (who is presumed innocent) has the same position as the prosecutor. Therefore the rights of the suspect or defendant must also be respected. To support the principle of presumption of innocence in law enforcement, the Criminal Code has given a set of rights that must be respected and protected by law enforcement.

Reksodipuro argues that the Asas Lagilitas, or the principle of presumption of innocence, is the main principle of due process of law, which includes at least the following:

1. Protection against arbitrary actions of state officials;

2. That it is the court that has the right to determine whether or not the accused is guilty;

3. That the court hearing must be open (must not be confidential);

4. That the suspect and the accused must be granted bail to be able to defend themselves fully.

In Indonesia, the BasicLawof 1945 does not explicitly apply in one particular Article on guilt's presumption. This principle can be found in the implementation legislation, namely in Law No.14 of 1970 as amended by Law No. 35 of 1999, which was replaced by Law No. 4 of 2004 on The Power of Justice and returned with Law No. 48 of 2009 on Judicial Power. Law No. 39 of 1999 on Human Rights, Law No. 8 of 1981 on Criminal Procedural Law and Chapter III of the Decree of the Minister of Justice of the Republic of Indonesia Number M.01PW.07.03 Thun 1982 concerning Guidelines for the Implementation of the Criminal Procedure Law.

Also to the Criminal Code and The Basic Law1945 in Law No. 48 of 2009 on the Power of Justice expressly stated in Article 8 Paragraph (1) which states that "Every person who is suspected, arrested, detained, prosecuted, and confronted before the Court, must be considered innocent before the court's decision, which states his guilt that obtains a permanent legal force." Meanwhile, in Law No.8 of 1981, the principle of presumption of innocence is not expressly stated in any of the articles. Still, it is implied in the section considering the number 3 and the General Explanation number 3 letter c. 
When looking back at the explanation above, how important it is to pay attention to the proper functioning of the Principle of Legality in the proof system is limited according to Law Number 8, the year 2010. After all, based on the analysis of the author, it is considered to potentially stab human rights because it is contrary to the principle of presumption of innocence (presumption of innocence), because if seen from the sound of Article 77, "Terdakwa has the right to prove that he did not commit the crime alleged against him and the public prosecutor remains obliged to prove his indictment." Whereas referring to Asa's legality principle, a person can not be found guilty before a court ruling that inkhract van bewist gedaan, meaning the defendant plays an active role in the evidence. In addition to the system embraced by Law No. 8 of 2010 on the reverse evidentiary system, not only KUHAP but also contrary to Law No. 48 of 2009 concerning Justice, which can issue a wrongful verdict not a person is a judge.

\section{Conclusion}

That is the explanation of Law No.8 of 2010, Concerning The Crime of Money Laundering, that the system of "inverse proof of a limited and balanced" nature, namely the defendant has the right to prove that he did not commit the crimes alleged against him and the public prosecutor remains obliged to prove his indictment. It is meant by a "limited nature" that if the accused can confidently demonstrate that the allegations directed against him are not proven or untrue, this does not mean that the defendant did not commit a criminal offense following what was alleged by the JPU. Because JPU, still obliged to prove the indictment.

\section{References}

[1] Aziz Syamsudin, 2001, Tindak Pidana Khusus, Jakarta: Sinar Grafika.

[2] Bismar Nasution, 2008, Rezim Anti Money Laundring di Indonesia Bandung: Books Terrace dan Library.

[3] Heri Tahir, 2010, Proses Hukum Yang adil dalam sistem peradilan Pidana di Indonesia. Yogyakarta: LaksBang PRESSindo,

[4] Ivan Yustiavandana (dkk), 2010, Tindak Pidana Pencucian Uang di Pasar Modal, Bogor: Ghalia Indonesia.

[5] N.H.T. Siahaan, 2005 Pencuncian Uang dan Ketajaman Perbankan, Jakarta: Cetakan Kedua , Edisi-Revisi

[6] Sutan Remy Sjahdeini, 2007, Seluk Beluk Tindak Pidana Pencuncian Uang dan Pembiayaan Terorisme, Jakarta: Pustaka Utama Grafiti.

[7] Tb Irman S, 2006, Hukum Pembuktian Pencucian Uang. Bandung: Pustaka Sinar Harapan, Cetakan Pertama, Publishing.

[8] Mardjono Resksodiputro, 1995 , Hak Asasi Manusia dalam Sistem Peradilan Pidana, Jakarta: Pusat Pelayanan Keadilan dan Pengabdian Hukum Universitas Indonesia.

[9] Bambang Setioprojo, 2010, Money Laundering pandangan dalam pengaturan, Jurnal hukum bisnis, volume 3 , jakarta.

[10] http://jambi-kito.blogspot.com/2012/04/pengaturan-asas pembuktianterbalik19.html, diakses pada 8 Maret 2015, Surakarta 